\title{
Romanianization and Half-Hearted Concessions. The Last Four Years of German-Language Education in Southern Bessarabia (1936-1940) ${ }^{12}$
}

\author{
Philippe Henri BLASEN
}

\begin{abstract}
The article discusses the status of German-language education in Southern Bessarabia in the last years of Romanian domination, before the Soviet takeover in June 1940 and the subsequent resettlement of the local German population in September 1940. It shows that neither the national-liberal government (1933-1938), nor the regime of King Carol II (1938-1940) complied with the 28 October 1920 treaty between the principal allied powers and Romania respecting Bessarabia, an agreement which granted the Romanian nationals of German ethnicity the right to establish and manage schools, as well as to use the German language in the educational sphere. Both the national-liberal government and the regime of King Carol II obstructed public and confessional German-language education in Southern Bessarabia. They did not restore school buildings confiscated in 1936 and did not authorize the establishment of German-language schools. Only in September 1939 did the regime of King Carol II make some palpable concessions to the Germans of Southern Bessarabia, apparently as a result of the departure of the autonomist leader of the German community in Romania. However, even then, the Romanian state did not return all of the confiscated school buildings and seemingly further pursued the Romanianization of the local Germans.
\end{abstract}

Keywords: Education, minorities, Bessarabia Germans, Romanianization, regime of Carol II.

During World War I, Germans in Southern Bessarabia, who had settled in the region during the first half of the 19th century, changed their political stance several times in response to the course of the events and the attitudes of the successive rulers. Though loyal to Russia, they became the target of a persecution by the tsarist authorities. In 1915, two emergency laws led to the seizure or the compulsory sale of their lands, a number of Germans were deported, and the German language was banned from education and Church service. After the 1917 February Revolution, the emergency laws were rescinded, but the land was not returned to the Germans. They held several meetings, demanding the res-

1 This work was supported by a grant of the Romanian Ministry of Research and Innovation, CCCDI - UEFISCDI, project number PN-III-P1-1.2-PCCDI-2017-0116, within PNCDI III.

2 I would like to thank Andrei Cușco and Catherine Gibson for their contributions. 
toration of their autonomy and the recognition of their economic, social, and cultural rights. In late 1917 and in 1918, the Germans requested the protection of the German Empire and some of their local leaders envisaged the creation of an autonomous region in Southern Bessarabia, a union with Austrian-ruled Ukraine, or even their resettlement to Germany. ${ }^{3}$ Almost a year after Sfatul Țării proclaimed the union of the Moldavian Democratic Republic (Bessarabia) with Romania on 9 April 1918 (Julian calendar: 27 March 1918), a congress of German settlers convened in the commune of Tarutino on 20 March 1919 (Julian calendar: 7 March 1919) and declared their allegiance to Romania. The congress referred to the decisions of Sfatul T,ării "that every nation has the right to be led, taught, administrated, and judged in its own language and by its own sons, and to have a corresponding representation in the legislature and the government, which representation guarantees the autonomy of the Church and the school, as well as the rights owed to the German settlers". ${ }^{4}$ This reference was anachronistic, as Sfatul T,ării had abandoned the conditions for the union on 10 December 1918 (Julian calendar: 27 November 1918), ${ }^{5}$ which included "respect for the rights of the minorities in Bessarabia”. ${ }^{6}$ However, when on 3 March 1920 the Supreme Council of the Paris Peace Conference declared itself ready to recognise the treaty on "the reunion of Bessarabia with Romania", the Supreme Council also considered "that the rights of minorities in [Bessarabia] should be guaranteed on the same terms as those residing in other parts of the Romanian Kingdom", with the possibility of an arbitration of the League of Nations. ${ }^{7}$ A provision to this effect was included under Article 3 of the 28 October 1920 treaty between the principal allied powers and Romania respecting Bessarabia. ${ }^{8}$ The

3 Svetlana Suveică, "Negotiating Loyalty: The Bessarabian Germans from the Russian Empire to the Romanian Nation-State (1917-1919)," in Mutter: Land - Vater: Staat: Loyalitätskonflikte, politische Neuorientierung und der Erste Weltkrieg im österreichisch-russländischen Grenzraum, ed. Florian Kührer-Wielach and Markus Winkler (Regensburg: Friedrich Pustet, 2017), 135-152.

4 Ștefan Ciobanu, Unirea Basarabiei: Studiu și documente cu privire la mișcarea națională din Basarabia în anii 1917-1918 (București: Cartea Românească, 1929), 258-260 (doc. 174): „că fiecare nație are dreptul de a fi condusă, educată, administrată și judecată în limba sa și de fii săi și să aibă reprezentare corespunzătoare în corpurile legiuitoare și în guvern, care reprezentare garantează autonomia bisericii și școalei precum și drepturile cuvenite coloniștilor germani”.

5 Ciobanu, Unirea Basarabiei, 276-277 (doc. 195).

6 Ciobanu, Unirea Basarabiei, 239-240 (doc. 160): „Respectarea drepturilor minorităților din Basarabia."

7 The National Archives, CAB 24/99/86, 260: Statement of the Supreme Council on Bessarabia, 03.03.1920.

8 "Treaty between the principal allied powers and Roumania respecting Bessarabia of 28 October 1920," The American Journal of International Law 17, no. 1 Supplements (January 1923): 7-11. 
article provided for the observance of the treaty between the principal allied and associated powers and Romania that had been signed in Paris the previous year on 9 December 1919. This treaty granted the Romanian nationals the right "to establish, manage and control at their own expense [...] schools and other educational establishments, with the right to use their own language $[. .$.$] ". It further stipulated that "Romania will provide in the public educational$ system in towns and districts in which a considerable proportion of Romanian nationals of other than Romanian speech are resident adequate facilities for ensuring that in the primary schools the instruction shall be given to the children of such Romanian nationals through the medium of their own language" (art. 10). ${ }^{9}$

On the one hand, even though the 28 October 1920 treaty between the principal allied powers and Romania respecting Bessarabia was never ratified by Japan, it was in Romania's interest to strictly abide by it so that the recognition of the union would not be questioned. On the other hand, Germany, who was most concerned by the fate of the Germans in Southern Bessarabia, was not party to the treaty.

This article examines the evolution of German-language education in Southern Bessarabia from the confiscation of the school buildings from the Evangelical Church in autumn 1936 to the cession of Bessarabia to the Soviet Union on 28 June 1940, which led to the resettlement of the local Germans organised by Germany from 15 September $1940 .{ }^{10}$ It argues that the Romanian state did not grant the minorities the above-mentioned rights enshrined in the treaty of 28 October 1920 and that the rapprochement between Romania and Germany under the regime of King Carol II (10 February 1938-5/6 September 1940) had only a limited positive impact on German-language education in Southern Bessarabia.

From 1923, German had been gradually replaced by Romanian as the language of instruction in the public schools in the German settlements of Bessarabia. ${ }^{11}$ Certain confessional schools were dissolved as early as 1924 in the context of Minister Constantin Angelescu's policy to create a national (Romanian)

9 "Treaty between the principal allied and associated powers and Roumania of 9 December 1919," League of Nations Treaty Series 5, no. 1-4 (1921): 343.

${ }^{10}$ Dirk Jachomowski, Die Umsiedlung der Bessarabien-, Bukowina- und Dobrudschadeutschen: Von der Volksgruppe in Rumänien zur „Siedlungsbrücke” an der Reichsgrenze (München: R. Oldenbourg, 1984), 71.

${ }^{11}$ Luminița Fassel, Das deutsche Schulwesen in Bessarabien (1812-1940): Eine komparativ-historische und sozio-kulturelle Untersuchung (München: Verlag Südostdeutsches Kulturwerk, 2000), 123-129. 
school. ${ }^{12}$ The Romanian authorities could profit from the uncertain status of the school buildings. As Professor Karl Liebram from Cetatea-Albă wrote in 1925:

I cannot make a valid statement if our schools are public or confessional, since the question is still unresolved. We always have had purely confessional local schools and our political representatives continuously endeavour to restore the former situation of our schools, which, in several villages, has been turned upside down in the course of the last eight years. ${ }^{13}$

Following the electoral victory of the National-Liberal Party in December 1933, Constantin Angelescu was once again appointed Minister of Education. This was probably the main reason why German language education in Southern Bessarabia was further undermined. No German teacher was appointed beginning with $1933 .{ }^{14}$ Native German-speaking teachers were replaced with Romanians. According to historian Luminița Fassel, the number of the former fell from 202 to 136 (or from 202 to 124, according to historian Ute Schmidt) between 1933 and 1938 and the number of the latter rose from 81 to 124 (or from 81 to 238 ) over the same period. ${ }^{15}$ Almost half of the 140 German communes remained without a German teacher. ${ }^{16}$ For instance, after 1934 in Marienfeld, Tighina county, there were only ethnic Romanian teachers. ${ }^{17}$ In autumn 1936, the state even confiscated the school buildings and teachers' homes from the Evangelical Church of Augustan Confession. ${ }^{18}$ The

${ }^{12}$ Fassel, Das deutsche Schulwesen, 131. Angelescu was the father of interwar national education in Romania: Irina Livezeanu, Cultural Politics in Greater Romania: Regionalism, Nation Building, \& Ethnic Struggle, 1918-1930 (Ithaca and London: Cornell University Press, 1995), 34-48.

${ }^{13}$ Serviciul Județean Sibiu al Arhivelor Naționale (from now on: SJSAN), fond Liga Culturală a Germanilor din România (179), dosar 10, 31: Karl Liebram to the Cultural Office of the Association of the Germans in Greater Romania, 10. December 1925: „Eine gültige Angabe darüber, ob unsere Schulen staatlich oder konfessionell sind, kann ich nicht machen, da diese Frage noch in der Schwebe ist. Wir haben aber von jeher reine konfessionelle Gemeindeschulen gehabt, u. unsere politische Vertretung unablässig bemüht, diese frühere Lage unserer Schulen, die in manchen Dörfern erst in den letzten acht Jahren über den Haufen geworfen ist, wiederherzustellen."

${ }^{14}$ Ute Schmidt, Die Deutschen aus Bessarabien: Eine Minderheit aus Südosteuropa (1814 bis heute) (Köln: Böhlau, 2004), 93.

${ }^{15}$ Fassel, Das deutsche Schulwesen, 175; Schmidt, Die Deutschen, 93.

${ }^{16}$ Schmidt, Die Deutschen, 93.

${ }^{17}$ Artur Bogner, „Chronik der Gemeinde Marienfeld, Kreis Tighina,” Deutscher Volkskalender für Bessarabien, 1937, 63.

${ }^{18}$ Die Rumäniendeutschen zwischen Demokratie und Diktatur: Der politische Nachlass von Hans Otto Roth 1919-1951, ed. Klaus Popa (Frankfurt/Main: Peter Lang, 2003), 554-556 (doc. 309). 
exact moment of the confiscation could not be ascertained, but the number of seized buildings purportedly amounted to $140,{ }^{19}$ suggesting that the schools of all German communes were seized. A German delegation headed by Hans Otto Roth, the chairman of the German Party parliamentary group, which had represented the whole German minority since 1935, discussed the issue with the Minister of the Interior in late November or early December 1936. Roth emphasised that the parishes had been stripped of their rents (paid for by the state), that some German teachers had been forced to hand over their living quarters to ethnic Romanian teachers, and that the Evangelical Church could no longer consider the establishment of confessional (private) schools. These were perhaps the very reasons why the Romanian state had confiscated the buildings, so as to slash the costs and to speed up the Romanianization of the German communes. Eventually, the Minister and Roth agreed on creating a mixed commission. ${ }^{20}$

However, hostility to German-language education in Southern Bessarabia persisted. A local German newspaper, Deutsche Zeitung Bessarabiens, published a letter on 17 November 1937 that had been sent by the school inspectorate of Cetatea-Albă county to the district consistory of the Evangelical Church in Tarutino on 24 September 1937. The letter stated that the German language could be taught as an extracurricular subject for two hours a week if there were enough rooms available. The letter instructed the parishes to rent and furnish suitable rooms in order to get official permission. ${ }^{21}$ This was a slap in the face both for the Evangelical Church, which was expected to rent its own confiscated buildings, and for the local Germans whose ability to teach and learn their mother tongue was further restricted.

However, in the same autumn of 1937 the national-liberal president of the senate invited Roth to join the National-Liberal Party in the elections. ${ }^{22}$ According to Fritz Fabritius, who was the chairman of the Volksgemeinschaft der Deutschen in Rumänien, the larger political group of the German minority represented by the German Party in parliament, the Volksgemeinschaft had been unable to control the Deutsche Volkspartei, a small breakaway political group of the minority. As the national-liberals were announcing concessions, the

19 „Die Entscheidung,” Banater Deutsche Zeitung, November 30, 1937, 2.

20 „Eine Abordnung unserer Parlamentarier beim Innenminister: Die Frage unseres Kirchenvermögens,” Deutsche Zeitung Bessarabiens, December 2, 1936, 1

${ }^{21}$ „Schulisches,” Deutsche Zeitung Bessarabiens, November 17, 1937, 2; cf. „Zum Artikel „Schulisches” in Folge 92 der D.Z.B.," Deutsches Volksblatt (Tarutino), November 27, 1937, 3.

22 „Der große Appell an die deutschen Wähler,” Banater Deutsche Zeitung, December 14, $1937,2$. 
Volksgemeinschaft responded to their offer. ${ }^{23}$ The German Party attached several preconditions to an electoral agreement with the National-Liberal Party. Among the stipulations was that the government should return the confiscated buildings, respect the legal right to establish new confessional schools, and enforce the legal provision that the Ministry of Education establish public minority language primary schools. ${ }^{24}$ The German Party also requested that the graduates of the confessional teachers' school in Sărata/Sarata, Cetatea-Albă county, - the Wernerschule ${ }^{25}$ - be appointed at local public primary schools where the language of instruction was German. ${ }^{26}$ Fabritius announced the conclusion of the electoral agreement on 26 November 1937, emphasising that the chairman of the National-Liberal Party had promised to authorise the establishment of 21 confessional schools in Bessarabia and Bukovina, to introduce German language education in public schools with German pupils, and to return the school properties in Bessarabia. ${ }^{27}$ According to Roth, on 12 December 1937, the Ministry of Education gave Franz Kräuter of the German Party permission to open 18 confessional schools in Bessarabia and 2 in Bukovina. ${ }^{28}$ Minister Angelescu also ordered on 15 December 1937 that the legal provision concerning the establishment of public minority language primary schools be implemented in the communes where at least 30 German pupils attended public primary school. ${ }^{29}$ According to a "survey on the German colonists in the south of Bessarabia" by

23 „Aufruf des Landesobmanns," Siebenbürgisch-Deutsches Tageblatt, November 28, 1937, 1.

${ }^{24}$ Monitorul Oficial, no. 61, June 26, 1924, 8602-8629 (no. 2571, art. 7).

${ }^{25}$ The school was established in 1844 under Russian rule with a part of the legacy of Christian Friedrich Werner, a rich merchant from Giengen, Württemberg, who had emigrated to Sarata in 1823 , and had died there the same year. At the beginning, the school trained orphans as teachers and clerks for the German colonies without charging them fees. With the war, the school lost its endowment capital. The Romanian state did not subsidise the school, which had to rely on tuition fees and donations. The resulting rise of the tuition fees and the absence of professional prospects caused a decrease in the number of pupils: Karl Baisch, „Kurzgefaßte geschichtliche Übersicht der Gründung und des Bestehens der Kolonieen des sarataer Bezirkes (Schluß)," Unterhaltungsblatt für deutsche Ansiedler im südlichen Rußland, September, 1852, 66-67; Albert Mauch, „Zur Geschichte der Wernerschule zu Sarata,” Heimat Kalender für die Deutschen Bessarabiens, [1921], 76-77; Schmidt, Die Deutschen, 93-94.

${ }^{26}$ Die Rumäniendeutschen, 554-556 (doc. 309).

27 „Aufruf des Landesobmanns,” Siebenbürgisch-Deutsches Tageblatt, November 28, 1937, 1; cf. „Rückgabe unseres Schulvermögens,” Deutsches Volksblatt, December 1, 1937, 1-2.

28 „Der große Appell an die deutschen Wähler,” Banater Deutsche Zeitung, December 14, $1937,2$.

${ }^{29}$ Serviciul Județean Suceava al Arhivelor Naționale, fond Inspectoratul școlar al județului Baia (209), dosar 2/1938, 89 = fond Inspectoratul școlar al județului Rădăuți (238), dosar 3/1938: copy of ministerial order no. 213102 of 15 December 1937. 
the secret service SSI, three decisions by the Ministry of Interior even cancelled the confiscations. ${ }^{30}$ Prospects seemed bright for the Germans, ${ }^{31}$ that is, until the National-Liberal Party lost the elections on 20 December 1937.

The new far-right national-Christian cabinet also offered the Volksgemeinschaft an electoral agreement in late January 1938, ahead of the elections scheduled for early March. Amongst others, it pledged to implement the promises of the national-liberal government and to grant the Germans cultural autonomy. ${ }^{32}$ However, King Carol II staged a coup on 10 February 1938, before the elections were held.

The new regime approached the Deutsche Volkspartei and the Volksgemeinschaft to avoid a similar situation to that which had occurred in Czechoslovakia. ${ }^{33}$ The Volksgemeinschaft submitted a statute draft to the King and the Prime Minister in late July 1938, requesting the right to establish German-language schools, teach their own curricula, and train teachers for these schools. It also demanded legal autonomy for the German Churches, including the right to establish, administrate, manage, and finance confessional German language schools with their own curricula and a status equal to that of public schools. ${ }^{34}$ The regime published a cabinet decision concerning the regulation of the General Commissariat for Minorities on 4 August 1938, which reaffirmed amongst others the right of the minorities to establish, manage, and control schools, as well as exercise the right to use their own language. ${ }^{35}$ This stipulation was in accordance with the treaty between the principal allied and associated powers and Romania of 9 December 1919, which Article 3 of the 28 October 1920 treaty between the principal allied powers and Romania respecting Bessarabia referred to. However, the regime rejected the statute draft of the Volksgemeinschaft. In particular, Prime Minister Patriarch Miron Cristea declared to the German Minister Plenipotentiary Wilhelm Fabricius on 5 August 1938 that he deemed the number of German-language schools too large and that it would be

${ }^{30}$ Serviciul Arhive Naționale Istorice Centrale (from now on: SANIC), fond P.C.M. - S.S.I. (2379), dosar 74/1939, 17: report on the German colonists in the south of Bessarabia.

31 „Aufbauarbeit für deutsche Zukunft,” Siebenbürgisch-Deutsches Tageblatt, December 19, 1937, 1.

32 Politisches Archiv des Auswärtigen Amts, RAV Czernowitz, Paket 5/2: the German minister plenipotentiary to the Auswärtiges Amt, 3 February 1938.

${ }^{33}$ Rebecca Haynes, Romanian Policy towards Germany, 1936-40 (Houndmills: Macmillan Press, 2000), 71.

${ }^{34}$ SANIC, fond Direcția Generală a Poliției (2350), dosar 179/1938, 4-10: memorandum draft, 25 July 1938.

${ }^{35}$ Monitorul Oficial, no. 178, August 4, 1938, 3595 (no. 1750 bis, art. 1); 3588 (no. 2761, art. 3-3-b). 
in the Germans' own interest to reduce it. ${ }^{36}$ Cristea was thus already questioning the provisions which had entered into force the previous day. Meanwhile, the obligation to return the confessional school buildings that had been confiscated without a valid legal reason had not even been included in the final version of the cabinet decision. ${ }^{37}$

Two weeks later, on 16 August 1938, Hans Hedrich, Gustav Rösler and Franz Kräuter, who represented the Volksgemeinschaft, the Evangelical Church, and the Catholic Church, initiated discussions with the new General Commissioner for Minorities, Silviu Dragomir, and the acting Minister of Education, ${ }^{38}$ Armand Călinescu, a central figure of the regime. Kräuter summarised the past electoral agreements. The Undersecretary of State for National Education Dumitru T,oni promised Rösler to resolve the issue of public German language schools and teacher training. ${ }^{39}$ Dragomir announced to the delegates on 25 August 1938 that he had discussed their demands with the director of the Department of Confessional Education and that the decisions were, on the whole, favourable to the Germans. ${ }^{40}$ However, while Kräuter had the impression that Dragomir was supportive, ${ }^{41}$ in fact, the General Commissariat for Minorities and the General Commissioner for Minorities himself shared Cristea's view that the Germans had more than enough private schools. ${ }^{42}$

In particular, opposition to German language education in Southern Bessarabia resulted from the intent of the Romanian state to Romanianise the local Germans, as the contemporaneous survey by the secret service SSI confirms:

The whole teaching staff of German origin, which serves in these schools, is permeated by the deepes nism and is recalcitrant to all attempts of nationalisation. The professors and teachers, who form without an exception the basic element of national-socialist propaganda, boycott the Romanian teaching staff and the effort of national re-education. There have been cases in several villages where

\footnotetext{
${ }^{36}$ Johann Böhm, Die Deutschen in Rumänien und das Dritte Reich 1933-1940 (Frankfurt/Main: Peter Lang, 1999), 344-345 (doc. 21): the German minister plenipotentiary to the Auswärtiges Amt, 5 August 1938.

${ }^{37}$ SANIC, fond P.C.M. (299), dosar 24/1938, 154-155: cabinet decision draft.

${ }^{38}$ Monitorul Oficial, no. 140, June 22, 1938, 2968 (no. 2257).

${ }^{39}$ SJSAN, Comunitatea germanilor din România (348), dosar A71, 9-10: Franz Kräuter to Hans Otto Roth, 24 August 1938.

${ }^{40}$ SJSAN, Comunitatea germanilor din România (348), dosar A71, 9-10: Franz Kräuter to Hans Otto Roth, 25 August 1938.

${ }^{41}$ SJSAN, Comunitatea germanilor din România (348), dosar A71, 9-10: Franz Kräuter to Hans Otto Roth, 24 August 1938.

${ }^{42}$ E.g., SANIC, fond P.C.M. (299), dosar 30/1938, 3: report by a technical adviser of the general commissariat for minorities, approved by the commissioner.
} 
the Romanian teachers, as a result of the propaganda of their German colleagues, have been given no accommodation and have been sold no food, and have had to sleep on the school benches and to buy provisions from the neighbouring villages. ${ }^{43}$

A similar mindset could be found in the Ministry of Education. On 12 September 1938 Undersecretary Țoni, acting for the Minister of Education, cancelled the authorisations for confessional primary schools, which had purportedly been issued illegally. ${ }^{44}$ The permissions for the 18 schools that had been delivered in December 1937 were withdrawn ${ }^{45}$ for spurious reasons. ${ }^{46}$ The ministerial decision was published on 19 September $1938,{ }^{47}$ two days after an article had appeared in Deutsche Zeitung Bessarabiens in which the author had expressed his belief that the government would not continue to oppose German-language education..$^{48}$ Neither the district consistory of the Evangelical Church in Tarutino nor the affected communes were informed of the decision. The school inspector prohibited the confessional schools from using the rooms that the public schools had hitherto made use of, presumably in the same buildings that had been confiscated from the Evangelical Church. In response, the German sexton of Arciz, Cetatea-Albă county, padlocked the local school to keep out the ethnic Romanian teachers. The next day, the county prefect arrived in the village, broke the lock, and handed the building over to the public school. In protest, the vast majority of the German parents did not let their

${ }^{43}$ SANIC, fond P.C.M. - S.S.I. (2379), dosar 74/1939, 16-17: report on the German colonists in the south of Bessarabia: "Întreg Corpul Didactic de origină germană, care deservește aceste școli, este pătruns de cel mai adânc șovinism și refractar oricăror tendințe de naționalizare. Profesorii sau învățătorii, cari fără excepție sunt și elementul de bază al propagandei naționalsocialiste, boicotează corpul didactic român și opera de reeducare națională. În unele sate s'au întâmplat cazuri când învăţătorii români, în urma propagandei făcută [sic] de camarazii lor germani, nu erau primiți în gazdă de nimeni și nici nu li se vindea hrană, trebuind să doarmă pe băncile școlii și să-și procure alimente din satele apropiate.”; cf. fond P.C.M. (299), dosar 117/1939, 74: activity report by the cultural section of the ministry for minorities.

${ }^{44}$ Monitorul Oficial, no. 217, September 19, 1938, 4407 (no. 159678); cf. Schmidt, Die Deutschen, 105.

${ }^{45}$ SJSAN, Comunitatea germanilor din România (348), dosar E9, 2: letter by the German school counsellor in Tarutino, 22 November 1938.

${ }^{46}$ Schmidt, Die Deutschen, 105 (Politisches Archiv des Auswärtigen Amts, R 60199: Lörner, „Schulzwischenfall in Arzis”, 22 September 1938); SJSAN, Comunitatea germanilor din România (348), dosar E9, 5: letter by the parish priest in Albota, 17 November 1938.

${ }^{47}$ Monitorul Oficial, no. 217, September 19, 1938, 4407 (no. 159678).

${ }^{48}$ Hans Bender, „Wie stelle ich mir den Aufbau eines deutschen Schulwesens in Rumänien vor?” Deutsche Zeitung Bessarabiens, September 17, 1938, 1. 
children go to school the following day.$^{49}$ In the parish of Albota, Cahul county, the confessional school of Alexandru-cel-Bun/Alexanderfeld was inaugurated, but the county prefect did not participate as the county school inspectorate had informed him that the school had no rights and was only tolerated. Members of the county school inspectorate also told the parish priest that the confessional schools had no rights, that the permission for the confessional school in Alexanderfeld was void because certain exams had not been held, that the pupils should be transferred to the public school, and that the confessional school could be immediately closed. Later, the sexton of Alexanderfeld informed the parish priest of a letter by an education authority, which stipulated that the German language must not be taught any more at the local school. ${ }^{50}$ The worst aspect for some Germans, who strongly sympathised with national-socialist Germany, was that the prefect of Cahul county had not taken part in the inauguration of the German school in Alexanderfeld, but instead took part in that of the Czech school in Huluboaia. ${ }^{51}$

The delegate of the Volksgemeinschaft Hans Hedrich informed its headquarters on 20 September 1938 that the "original promise to open German private schools in Bessarabia and Bukovina had not been kept", but he hoped for a positive solution in the future. ${ }^{52}$ Two days later, Prime Minister Cristea promised to examine the issue. ${ }^{53}$ However, the events described above show that there were no immediate tangible results. In such circumstances, Fabritius demanded the end of the "persecutions" (Verfolgungen) against the Church and schools in Bessarabia, Banat, and Bukovina in a memorandum dated 14 October $1938 .{ }^{54}$

The Ministry of Education informed the consistory of the Evangelical Church in Sibiu, Transylvania, on 21 October 1938 that it had instructed the school inspectorates to organise, in accordance with the legal provisions, German-language education in public primary schools attended by at least

${ }^{49}$ Schmidt, Die Deutschen, 105 (Politisches Archiv des Auswärtigen Amts, R 60199: Lörner, „Schulzwischenfall in Arzis”, 22 September 1938).

${ }^{50}$ SJSAN, Comunitatea germanilor din România (348), dosar E9, 5: letter by the parish priest in Albota, 17 November 1938.

${ }^{51}$ SJSAN, Comunitatea germanilor din România (348), dosar E9, 8: school activity report.

52 SJSAN, Comunitatea germanilor din România (348), dosar D35 - D40, 6-7: letter by Hans Hedrich, 20 September 1938: „Die ursprüngliche Zusage der Eröffnung deutscher Privatschulen in Bessarabien und Bukowina wurde nicht eingehalten, doch wird mit Hoffnung auf Erfolg in dieser Sache weitergekämpft.”

${ }^{53}$ SJSAN, Comunitatea germanilor din România (348), dosar D38: minute by Hans Hedrich. ${ }^{54}$ SJSAN, Comunitatea germanilor din România (348), dosar D40: memorandum by Fritz Fabritius. 
30 German pupils. ${ }^{55}$ By all accounts, this was the order that the Ministry had given a year earlier, on 15 December 1937, and which the Minister, either Victor Iamandi or bishop Nicolae Colan, had blocked in spring 1938, deeming it an illegal advantage. ${ }^{56}$ No evidence could be found that it was implemented in Bessarabia in autumn 1938. On the contrary, it would seem that Romanianization through public education continued. Thus, the two first levels of the German section of the public primary school in Tarutino were moved into the same building as the Romanian section on 1 September 1938. The General Commissariat for Minorities defended this decision, arguing that there needed be a "spiritual rapprochement" (o apropiere sufletească) between the locals. ${ }^{57}$ The climate in the German communes of Southern Bessarabia was presumably tense. The Ministry of Education ordered the local ethnic Romanian teachers in the public schools to be tactful and "not provoke by attempts of majoritarian pretentiousness" (să nu provoace prin încercări de ostentație de majoritar), such as by displaying ethnic superiority. ${ }^{58}$

The Ministry of Education placed a lot of emphasis on its decision of 22 October 1938 that minority languages be taught in several public schools for teachers. German became a study subject in Caransebeș (Banat), Sibiu (Transylvania), and Cernăuți (Bukovina). ${ }^{59}$ This decision was crucial for German language education, as it provided for the previously neglected ${ }^{60}$ training of German teachers for public German language schools and allowed for the prospect of restoring German-language education in Romanianised schools.

The odds turned in favour of the Germans in Southern Bessarabia after Petre Andrei was appointed Minister of Education on 6 December $1938 .{ }^{61}$ This probably had less to do with the personality of Andrei, a former member of the National Peasant Party ${ }^{62}$ and professor of sociology and ethics at the University of Iași, ${ }^{63}$ who had served as Undersecretary of State for Public Education in 1932

${ }^{55}$ SJSAN, Comunitatea germanilor din România (348), dosar E9, 7: the bishop of the Evangelical Church to the district consistory in Tarutino, 15 November 1938.

${ }^{56}$ SANIC, fond P.C.M. (299), dosar 33/1938, 19: report on the state of mind of the Germans in Romania.

${ }^{57}$ SANIC, fond P.C.M. (299), dosar 33/1938, 18: report on the state of mind of the Germans in Romania.

${ }^{58}$ SANIC, fond P.C.M. (299), dosar 117/1939, 73-74: activity report by the cultural section of the ministry for minorities.

${ }^{59}$ Monitorul Oficial, no. 249, October 26, 1938, 5077 (no. 189210).

${ }^{60}$ SANIC, fond P.C.M. (299), dosar 33/1938, 16: report on the state of mind of the Germans in Romania.

${ }^{61}$ Monitorul Oficial, no. 284, December 6, 1938, 5819 (no. 4117).

${ }^{62}$ Monitorul Oficial, no. 301, December 30, 1937, 9826.

${ }^{63}$ Anuarul Universității pe anul academic 1936/1937 (Iași), 1938, 97. 
and 1933, than with the relations between Romania and Germany. After King Carol II met the German Chancellor Adolf Hitler in Berchtesgaden, Bavaria, on 24 November 1938, the Romanian government had the Iron Guard leader Corneliu Zelea Codreanu killed during the night of 29-30 November 1938. As a result, Hitler was angered, because it looked as if he had agreed to the murder. Therefore, it was in the best interest of Romania to take "conciliatory measures" (Rebecca Ann Haynes). ${ }^{64}$ Improving the status of the German minority was an obvious choice, as Field Marshal Hermann Göring had told Carol II on 26 November 1938 in Leipzig, Saxony, that "the German relation with Romania was substantially influenced by the treatment of the German minorities [sic]" ${ }^{65}$

Minister Andrei received Hedrich on 21 December 1938. According to the newspapers of the German minority, Andrei promised to examine the requests for permissions to establish new private schools and to take the necessary steps for their solution in accordance with the law. He also agreed to restore public German-language education on the basis of a plan that Rösler had prepared in the past under his direction, ${ }^{66}$ presumably at the time when Andrei had been Undersecretary of State for Public Education.

In parallel, the regime pressed the Volksgemeinschaft to join the Front of National Rebirth, the single party it had created on 16 December $1938 .{ }^{67} \mathrm{Com}-$ missioner Dragomir freely admitted that this move would help repair relations between Romania and Germany. ${ }^{68}$ The Volksgemeinschaft imposed conditions, repeating the demands related to German language education previously stated in its statute draft and requesting the restitution of the properties of the Evangelical Church in Bessarabia. ${ }^{69}$ In an assessment, the cultural section of the General Commissariat for Minorities took a favourable view of the opening of the 20 confessional schools in Bessarabia and Bukovina. It backed the establishment of German-language sections at public schools in communes with German inhabitants with more than 30 pupils, and where there was no exist-

${ }^{64}$ Haynes, Romanian Policy, 72-73; 172-173.

${ }^{65}$ Akten zur deutschen auswärtigen Politik 1918-1945: Serie D (1937-1945): Band V (Baden-Baden: Imprimerie nationale, 1953), 289 (doc. 257): minute, 30 November 1938: „Der Feldmarschall betonte, daß das deutsche Verhältnis zu Rumänien wesentlich beeinflußt würde durch die Behandlung der deutschen Minderheiten.”

${ }^{66}$ „Deutsche Vorsprache bei der Regierung: Beim Unterrichtsminister,” Siebenbürgisch-Deutsches Tageblatt, December 24, 1938, 1; „Politische Übersicht,” Groß-Kokler Bote \& Schäßburger Zeitung, January 1, 1939, 1.

${ }^{67}$ Monitorul Oficial, no. 293, December 16, 1938, 5972 (no. 4321).

${ }^{68}$ SJSAN, Comunitatea germanilor din România (348), dosar D41, 4-6: minute by Hans Hedrich, 21 December 1938.

${ }^{69}$ SANIC, fond P.C.M. (299), dosar 288/1939, 29-57: German demands. 
ing confessional German-language school. The cultural section also proposed to introduce a special exam that would allow the graduates of the confessional teachers' schools to teach at the German-language sections of public schools. However, the assessment was evasive on the subject of the restitution of the properties of the Evangelical Church in Bessarabia:

It is a difficult issue. These are the properties used in the past by the German communities in Bessarabia. Strictly speaking, they are not Church properties. They were public goods, stemming from the donations of the Russian tsars in the 18th [sic] century for the use of the German colonies, for cultural purposes. The right of ownership, if they belong to the state or the communities, has always been open to debate. The Ministry of National Education has studies on the subject. These goods were allotted to the use of the primary schools - declared public - of the German communes in 1936. As a result, they still have been indirectly used for the benefit of the population. The resolution of this issue calls for a fundamental examination. Thereafter, a solution can be adopted with full knowledge of the facts. ${ }^{70}$

The cultural section of the General Commissariat for Minorities tried to make a specious argument in favour of the confiscation, based on the ambiguous legal status of properties in imperial Russia. However, as the SSI clearly stated, "each colony built its own school in the first years of its existence, with the support of the other colonies or alone, but on no account with the support of the state". ${ }^{71}$

At one point, the General Commissariat for Minorities presumably communicated the demands of the Volksgemeinschaft to the Ministry of Education. ${ }^{72}$ After the Volksgemeinschaft signed an agreement with the government on 10 January 1939 to join the Front of National Rebirth, Minister Andrei received Commissioner Dragomir and Hedrich on 26 January 1939. According to the

${ }^{70}$ SANIC, fond P.C.M. (299), dosar 288/1939, 292: report by the cultural section of the general commissariat for minorities: „Chestiunea este complicată. Este vorba de bunurile întrebuințate mai înainte de comunitățile germane din Basarabia. $\mathrm{Nu}$ sunt propriu zis averi bisericești. Au fost bunuri de interes public, provenite din donațiile Țarilor ruși în veacul al XVIII pentru utilitatea coloniilor germane în scopuri culturale. Dreptul de proprietate, dacă sunt ale Statului sau ale Comunităților, a fost întotdeauna discutat. La Ministerul Educaţiei Naţionale se află studii referitoare la această problemă. În 1936 - aceste bunuri au fost date pentru întrebuințarea școlilor primare - declarate de Stat - din comunele germane, deci indirect se utilizează tot pentru folosul populației. Rezolvarea problemei reclamă studii temeinice. Pe urma se va putea adopta o soluție cu bună înțelegere.”

${ }^{71}$ SANIC, fond P.C.M. - S.S.I. (2379), dosar 74/1939, 16: report on the German colonists in the south of Bessarabia: „Fiecare colonie și-a construit școală proprie încă din primii ani ai existenței sale, fie cu concursul celorlalte colonii, fie singură, însă în nici un caz cu concursul Statului."

${ }^{72}$ SANIC, fond P.C.M. (299), dosar 288/1939, 36: German demands. 
newspapers of the German minority, Dragomir showed support for the German demands and Andrei made promises, although with restrictions. He promised to immediately resolve the existing requests for permissions to establish new confessional schools, but specified that most of them could be implemented only at the beginning of the following school year. He declared that he would not hamper the restitution of the confiscated properties of the Evangelical Church in Bessarabia, whose fate, however, was in the hands of the Ministry of the Interior. He also announced that public German-language education would be reintroduced in accordance with the existing legal provisions, but that the order (of 15 December 1937?) would come fully into effect only the following school year, because a large part of the teachers at the public German language schools did not know German. He also promised to grant the graduates of the confessional teachers' schools the full right to be appointed at public German language schools, after they would take teaching classes during the summer break and pass an exam. ${ }^{73}$ Accordingly, the Minister of Education authorised on 1 February 1939 that confessional German language schools be established in communes with a large German population and the minimum legal percentage of pupils. The Minister also issued instructions that requests for permissions to establish such schools be examined as soon as possible and the competent authorities be asked immediately for their recommendations regarding existing requests. ${ }^{74} \mathrm{He}$ also decided on 14 February 1939 to reserve $20 \%$ of the slots at the higher teachers' schools for minority secondary teacher candidates. ${ }^{75}$

These and some other concessions ${ }^{76}$ had little, if any, impact. ${ }^{77}$ Quite the opposite, the Ministry of Education rejected all the requests for minority sections at public schools. This prompted a reaction by the General Commissariat for Minorities, which was not only afraid that the minorities would continue to be dissatisfied, but was also aware that the state had a greater influence on the minorities through these sections than via confessional schools. The General Commissariat pleaded for the establishment of a number of sections, among which one German-language section in Catzbach/Katzbach, Cetatea-Albă

73 „Politische Übersicht,” Groß-Kokler Bote \& Schäßburger Zeitung, January 29, 1939, 2.

${ }^{74}$ SANIC, fond P.C.M. (299), dosar 127/1939, 31: ministerial decision no. 20289/1 February 1939; cf. „Die Freiheit der Errichtung konfessioneller Schulen,” Siebenbürgisch-Deutsches Tageblatt, February 7, 1939, 2; „Konfessionelle (Kirchen-) Schulen mit deutscher Unterrichtssprache," Deutsches Volksblatt, February 8, 1939, 1.

${ }^{75}$ Monitorul Oficial, no. 44, February 22, 1939, 907 (no. 28388).

${ }^{76}$ SANIC, fond P.C.M. (300), dosar 203/1940, 1-16: report by the cultural section of the ministry for minorities.

${ }^{77}$ Politisches Archiv des Auswärtigen Amts, RAV Czernowitz, Paket 2/2: the German minister plenipotentiary to the Auswärtiges Amt, 8 April 1939. 
county, as well as for the creation of a mixed commission together with the Ministry of Education. ${ }^{78}$

The May issue of Mitteilungen des ev.-luth. Bezirkskonsistoriums für den Schulverein [Bulletin of the Evangelical Lutheran district consistory regarding the school association] proved the assessment of the General Commissariat for Minorities right. Written in a nationalist key, the bulletin suggested that the definitive resolution of the "school issue" (Schulfrage) required the establishment of confessional schools in all the communes and their financing by the local Germans. It described public schools as places where children were taught to sing, play, pray and live in a "non-German language" (nichtdeutsche Sprache) and forced or lured to adopt the "mindset of an alien ethnicity" (fremdvölkische Gesinnungsart). The bulletin was particularly alarmed by the attraction and magnetism of Straja Țării [Sentinel of the Country], King Carol II's single youth organisation. It appealed for the safeguarding and the expansion of the confessional teachers' school in Sarata, underscoring the need to finish this new construction project during the summer, and announced a fundraiser on 29 May $1939 .{ }^{79}$ Posted copies of the bulletin and an accompanying order by the illegal German organisation Nationale Arbeitsfront were seized by the police on 22-24 May 1939. The competent police inspectorate at first informed the general police directorate about these documents because of the bulletin's criticism of Straja Țării, but made it clear in a later message that it had also found fault with the appeal to establish confessional schools. ${ }^{80}$

Perhaps as a result of the recommendations of the General Commissariat for Minorities, the new law on primary education and teacher training, published on 27 May 1939, stated that public minority language schools or minority sections could be established in localities with a very large minority population and at least 20 children of school age (art. 7). ${ }^{81}$ While fixing a minimum number of pupils, this provision diluted the former legal framework, which had compelled the Ministry of Education to establish public minority language primary schools and which had not required the minority population to be of a

\footnotetext{
${ }^{78}$ SANIC, fond P.C.M. (299), dosar 151/1939, 34-37: report by the general commissariat for minorities.

79 SANIC, fond Direcția Generală a Poliției (2350), dosar 210/1939, 3-7: Mitteilungen des ev.luth. Bezirkskonsistoriums für den Schulverein, no. 3, May 1939.

${ }^{80}$ SANIC, fond Direcția Generală a Poliției (2350), dosar 210/1939, 9: the police inspectorate of the Dniester Region to the general police directorate, 23 May 1939; 8: the general police directorate to the police inspectorate of the Dniester Region, 24 May 1939; 10: the police inspectorate of the Dniester Region to the general police directorate, 24 May 1939.

${ }^{81}$ Monitorul Oficial, no. 121, May 27, 1939, 3377-3393 (no. 2184).
} 
specific size. ${ }^{82}$ Making the establishment of public minority language schools and minority sections optional was a clear infringement of the treaty between the principal allied and associated powers and Romania of 9 December 1919 and of the treaty between the principal allied powers and Romania respecting Bessarabia of 28 October 1920. The new law also allowed the Ministry of Education to establish special teachers' schools for minorities (art. 221). ${ }^{83}$ Simultaneously, the Ministry of Education confirmed the "right of publicity" of the confessional teachers' school in Sarata around 1 June 1939, which granted it a status close to that of a public school. ${ }^{84}$ However, the ministerial decision specified that the diplomas issued by the school were valid only for confessional, and not for public schools. ${ }^{85}$ Hence, it was clear that the Ministry intended to separate public and confessional teachers' training.

On Hedrich's proposal, Kräuter was appointed as school inspector for German-language schools on 15 June 1939. According to the newspapers of the German minority, Hedrich and the leaders of the Volksgemeinschaft in Bessarabia and Bukovina, Otto Broneske and Martin Runzer, had a meeting with Minister Andrei on the same day. The latter renewed his promises, and the representatives of the Volksgemeinschaft and the Minister agreed that the German school counsellors should submit proposals to Kräuter, who would communicate them to Andrei. ${ }^{86}$

Meanwhile, the chair of the Volksgemeinschaft Fabritius had become overly authoritarian and autonomist. His illegal actions included expanding the abovementioned Nationale Arbeitsfront. Prime Minister Călinescu did not want to take any steps on his own against Fabritius, so as not to provoke Germany. ${ }^{87}$ Instead, he tried to bring the German minority into line with threats and promises. When Hedrich asked him on 22 July 1939 to resolve the issue of the school buildings in Bessarabia, Călinescu told him that the Volksgemeinschaft had first to get rid of the hurdles, so that they could establish a good relationship with the government. ${ }^{88}$ Accordingly, after the Reich forced Fabritius to leave for Berlin in mid-

\footnotetext{
${ }^{82}$ Monitorul Oficial, no. 61, June 26, 1924, 8602-8629 (no. 2571, art. 7).

${ }^{83}$ Monitorul Oficial, no. 121, May 27, 1939, $3377-3393$ (no. 2184).

${ }^{84}$ Monitorul Oficial, no. 57, March 10, 1926, (no. 611, art. 88-98).

${ }^{85}$ Monitorul Oficial: Partea II-a, no 124, June 1, 1939, 5293 (no. 72554/1939).

${ }^{86}$ „Bedeutungsvolle Entscheidungen des Unterrichtsministers: Bestellung eines deutschen Landesschulinspektors,” Siebenbürgisch-Deutsches Tageblatt, June 17, 1939, 3; „Politische Übersicht," Groß-Kokler Bote \& Schäßburger Zeitung, June 25, 1939, 1; Monitorul Oficial, no. 141, June 22, 1939, 4024 (no. 107879).

${ }^{87}$ Die Rumäniendeutschen, 576-579 (doc. 330).

${ }^{88}$ SJSAN, Comunitatea germanilor din România (348), dosar A71, 17-22: minute by Hans Hedrich, 24 July 1939.
} 
August $1939^{89}$ and Hedrich raised the "Bessarabian school issue" (bessarabische Schulfrage) on 30 August, Călinescu summoned Andrei ${ }^{90}$ and informed Hedrich of his decision on 31 August, ${ }^{91}$ that is, one day before the beginning of the new school year ${ }^{92}$ and the German invasion of Poland. In agreement with Minister Andrei, all requests to establish confessional schools in Bessarabia were granted and all disputed school buildings and annexes were returned to the Evangelical Church, provided that the confessional schools would teach children to be loyal to the state. ${ }^{93}$ Despite this decision, only the primary school buildings in $57 \mathrm{com}$ munes where confessional schools were to be established were returned by a decree-law "for the donation of some school buildings to the Lutheran-Evangelical parishes in Bessarabia", dated 19 September 1939. ${ }^{94}$ In line with Călinescu's carrot-and-stick policy, the explanatory statement underscored that the "donation" was linked to the condition that the members of the communities concerned abide by the law and not plot against public order..$^{95}$ The permission to establish confessional schools in the "donated" buildings, dated 7 September 1939, was published on 23 September. ${ }^{96}$ The authorisation for six additional confessional schools, dated 21 September 1939, was printed on 27 September. ${ }^{97}$ Classes in the new building of the confessional teachers' school in Sarata, the Wernerschule, started on 15 September $1939^{98}$ and the same presumably happened in the confessional schools in October 1939.99

A report by the German legation in Bucharest of 15 February 1940, which attributed the restitution of the school buildings to the foreign policy of the

${ }^{89}$ Paul Milata, Zwischen Hitler, Stalin und Antonescu: Rumäniendeutsche in der Waffen-SS (Köln: Böhlau, 2009), 43.

${ }^{90}$ SJSAN, Comunitatea germanilor din România (348), dosar D42, 1-3: minute by Hans Hedrich.

${ }^{91}$ SJSAN, Comunitatea germanilor din România (348), dosar D42, 3: minute by Hans Hedrich.

92 „Der Schulbeginn an den Staatsschulen,” Siebenbürgisch-Deutsches Tageblatt, August 15, 1939, 1.

93 „Die Eröffnung deutscher Schulen und Rückgabe unseres Kirchenvermögens,” Deutsche Zeitung Bessarabiens, September 6, 1939, 3; „Die deutschen Schulen in Bessarabien genehmigt,” Deutsches Volksblatt, September 6, 1939, 2.

${ }^{94}$ Monitorul Oficial, no. 218, September 20, 1939, 5456 (no. 3425): „Decret-lege pentru donarea unor imobile școlare parohiilor lutherane-germane din Basarabia”.

${ }^{95}$ Monitorul Oficial, no. 218, September 20, 1939, 5456 (no. 160627).

${ }^{96}$ Monitorul Oficial, no. 221, September 23, 1939, 5502 (no. 161617).

${ }^{97}$ Monitorul Oficial, no. 224, September 27, 1939, 5539-5540 (no. 170931).

98 „Sarata,” Deutsche Zeitung Bessarabiens, September 30, 1939, 3-4; Jahrbuch (Kalender) der Deutschen Bessarabiens, 1940, 209. For the items the pupils needed to own, cf. „Aus der Wernerschule," Deutsche Zeitung Bessarabiens, September 13, 1939, 3.

99 „Wiedereröffnung des Unterrichts in deutschen Schulen Bessarabiens,” Siebenbürgisch-Deutsches Tageblatt, November 1, 1939, 1. 
Reich and particularly to the Molotov-Ribbentrop pact, did not mention the reintroduction of German-language education in public schools in Southern Bessarabia. ${ }^{100}$ On the contrary, in two German communes, Borodino and Culm/ Kulm, where new ethnic Romanian teachers had been appointed on 23 August $1939,{ }^{101}$ no confessional schools were authorised. It would therefore seem that Romanianization went on even during the school year 1939-1940. Only by way of a ministerial order of 15 March 1940 the furniture and the registers of the retroceded schools were handed over, while the state kept their archives. In late March 1940, the district consistory was still planning to open another 17 confessional schools. ${ }^{102}$ However, after the Soviet takeover of Bessarabia from 28 to 30 June 1940, the fate of the local Germans was sealed. Starting from 15 September 1940, the Reich resettled them to the territories it controlled.

In conclusion, neither the national-liberal government, nor the regime of King Carol II complied with the 28 October 1920 treaty between the principal allied powers and Romania respecting Bessarabia. Both the national-liberal government and the regime of King Carol II obstructed public and confessional German-language education in Southern Bessarabia. The national-liberal government took reparatory measures in autumn 1937, but the regime of King Carol II reversed them. The rapprochement between Romania and Germany under this regime had little, if any, impact on German-language education in Southern Bessarabia. The regime did not make palpable concessions to the Germans in Southern Bessarabia until September 1939. Even then, it did not return all of the confiscated school buildings and seemingly further pursued the Romanianization of the local Germans.

This policy was at odds with the authorisation of German sections in Sălaj and Satu-Mare counties as early as late $1938 .{ }^{103}$ In these counties bordering Hungary, the regime was interested in "re-Germanising" Magyarised Swabians and allowed for a certain development of German language and culture, in order to remove the group from Hungary's influence. The discrepancy in the regime's policy at the opposite ends of the country underscores how it disregarded its duties under the treaties of 9 December 1919 and 28 October 1920 as long as it was not facing pressure by another state. While the German group in Bessarabia was treated worse than that in Sălaj and Satu-Mare counties and

\footnotetext{
${ }^{100}$ Politisches Archiv des Auswärtigen Amts, RAV Czernowitz, Paket 3/1: the German minister plenipotentiary to the Auswärtiges Amt, 15 February 1940.

${ }^{101}$ Monitorul Oficial, no. 194, August 24, 1939, 5090-5091 (no. 151273).

${ }^{102}$ Cornelia Schlarb, Tradition im Wandel. Die evangelisch-lutherischen Gemeinden in Bessarabien 1814-1940 (Köln/Weimar/Wien: Böhlau, 2007), 479-480.

103 „Lehrerernennungen,” Sathmarer Schwabenpost, Dezember 20, 1938, 8.
} 
while Carol II's flirt with Hitler apparently did not impact the regime's policy towards this group, it still held a better status than the ethno-linguistic minorities that lacked a powerful patron. Thus, the Ukrainians in Northern Bukovina and in Bessarabia were denied an education in their language up to 1940.

Eventually, the stance of the national-liberal government and the regime of King Carol II reveals not only their disregard for international engagements pertaining to minorities, but also their lack of pragmatism. They appear not to have seen an advantage in transforming the Germans in Southern Bessarabia into assets against Soviet propaganda and agitation. German settlers in Southern Bessarabia had helped crush a Soviet-led rebellion in $1924 .{ }^{104}$ The influence of national-socialism turned the local Germans even more against Bolshevism. However, the national-liberal government and the regime of King Carol II chose to alienate these Germans by trying to Romanianise them rather than secure their loyalty through a favourable cultural policy.

\section{Rezumat}

Articolul examinează situația învățământului de limbă germană în Basarabia de sud în ultimii ani ai stăpânirii românești, înainte de trecerea provinciei sub puterea sovietică în iunie 1940 și a deplasării populației germane locale ce a urmat în septembrie 1940. Articolul arată că nici guvernul național-liberal (1933-1938), nici regimul personal al regelui Carol al II-lea (1938-1940) nu au respectat tratatul dintre principalele puteri aliate și România cu privire la Basarabia din 28 octombrie 1920, acord ce le dădea cetățenilor români de etnie germană dreptul de a deschide și de a administra școli și de a utiliza limba germană în cadru educațional. Atât guvernul național-liberal cât și regimul personal al lui Carol al II-lea au împiedicat educaţia publică și confesională de limbă germană din Basarabia de sud. $\mathrm{Nu}$ au retrocedat clădirile școlare confiscate în 1936 și nu au autorizat deschiderea de școli de limbă germană. Abia în septembrie 1939 regimul regelui Carol al II-lea le-a făcut concesii concrete germanilor din Basarabia de sud, se pare drept rezultat al plecării conducătorului autonomist al comunităţii germane din România. Însă, chiar și atunci, statul român nu a dat înapoi toate clădirile școlare confiscate și, după toate aparențele, a continuat românizarea germanilor locali.

Cuvinte-cheie: Învățământ, minorități, germani basarabeni, politica de românizare, regimul lui Carol al II-lea.

Philippe Henri Blasen, A. D. Xenopol Institute of History in Iași, Romania, and Centre de Documentation sur les Migrations humaines, Dudelange, Luxembourg. Email: blasen@protonmail.ch

${ }^{104}$ Schmidt, Die Deutschen, 92. 